\title{
Optical and geometrical aerosol particle properties over the United Arab Emirates
}

\author{
Maria Filioglou $^{1}$, Elina Giannakaki ${ }^{1,2}$, John Backman $^{3}$, Jutta Kesti ${ }^{3}$, Anne Hirsikko ${ }^{3}$, Ronny Engelmann ${ }^{4}$, \\ Ewan O'Connor $^{3}$, Jari T. T. Leskinen ${ }^{5}$, Xiaoxia Shang ${ }^{1}$, Hannele Korhonen ${ }^{3}$, Heikki Lihavainen ${ }^{3,6}$, \\ Sami Romakkaniemi ${ }^{1}$, and Mika Komppula ${ }^{1}$ \\ ${ }^{1}$ Finnish Meteorological Institute, Kuopio, 70211, Finland \\ ${ }^{2}$ Environmental Physics and Meteorology, Faculty of Physics, National and Kapodistrian University of Athens, \\ Athens, 15784, Greece \\ ${ }^{3}$ Finnish Meteorological Institute, Helsinki, 00560, Finland \\ ${ }^{4}$ Leibniz Institute for Tropospheric Research (TROPOS), Leipzig 04318, Germany \\ ${ }^{5}$ Faculty of Science and Forestry, University of Eastern Finland, Kuopio, 70211, Finland \\ ${ }^{6}$ Svalbard Integrated Arctic Earth Observing System, Longyearbyen, 9170, Norway
}

Correspondence: Maria Filioglou (maria.filioglou@fmi.fi)

Received: 14 February 2020 - Discussion started: 13 March 2020

Revised: 25 June 2020 - Accepted: 30 June 2020 - Published: 27 July 2020

\begin{abstract}
One year of ground-based night-time Raman lidar observations has been analysed under the Optimization of Aerosol Seeding In rain enhancement Strategies (OASIS) project, in order to characterize the aerosol particle properties over a rural site in the United Arab Emirates. In total, 1130 aerosol particle layers were detected during the 1-year measurement campaign which took place between March 2018 and February 2019. Several subsequent aerosol layers could be observed simultaneously in the atmosphere up to $11 \mathrm{~km}$. The observations indicate that the measurement site is a receptor of frequent dust events, but predominantly the dust is mixed with aerosols of anthropogenic and/or marine origin. The mean aerosol optical depth over the measurement site ranged at $0.37 \pm 0.12$ and $0.21 \pm 0.11$ for 355 and $532 \mathrm{~nm}$, respectively. Moreover, mean lidar ratios of $43 \pm 11 \mathrm{sr}$ at a wavelength of $355 \mathrm{~nm}$ and $39 \pm 10 \mathrm{sr}$ at $532 \mathrm{~nm}$ were found. The average linear particle depolarization ratio measured over the course of the campaign was $15 \pm 6 \%$ and $19 \pm 7 \%$ at the 355 and $532 \mathrm{~nm}$ wavelengths, respectively. Since the region is both a source and a receptor of mineral dust, we have also explored the properties of Arabian mineral dust of the greater area of the United Arab of Emirates and the Arabian Peninsula. The observed Arabian dust particle properties were $45 \pm 5(42 \pm 5) \mathrm{sr}$ at $355(532) \mathrm{nm}$ for the lidar ratio, $25 \pm 2 \%(31 \pm 2 \%)$ for the linear particle depo-
\end{abstract}

larization ratio at $355(532) \mathrm{nm}$, and $0.3 \pm 0.2(0.2 \pm 0.2)$ for the extinction-related Ångström exponent (backscatterrelated Ångström exponent) between 355 and $532 \mathrm{~nm}$. This study is the first to report comprehensive optical properties of the Arabian dust particles based on 1-year long observations, using to their fullest the capabilities of a multi-wavelength Raman lidar instrument. The results suggest that the mineral dust properties over the Middle East and western Asia, including the observation site, are comparable to those of African mineral dust with regard to the particle depolarization ratios, but not for lidar ratios. The smaller lidar ratio values in this study compared to the reference studies are attributed to the difference in the geochemical characteristics of the soil originating in the study region compared to northern Africa.

\section{Introduction}

The Earth's energy budget involves the exchange of energy between three levels: its surface, the top of the atmosphere, and the atmosphere in between (Hansen et al., 2005). In this system, aerosol particles are an important, yet underdetermined, component introducing uncertainties in weather and climatic predictions (Boucher et al., 2013; Stevens and Fein- 
gold, 2009). Additionally, aerosol particles are tied to health (Davidson et al., 2005), biological processes (Kanakidou et al., 2018; Moore and Braucher, 2008), and aviation safety (Guffanti et al., 2010; Lechner et al., 2017). Mineral dust is one of the most mass-abundant types of primary aerosol particles emitted into the atmosphere (Kok et al., 2017). Northern Africa is the major contributor of mineral dust in the atmosphere $(50 \%-70 \%)$, followed by deserts in the Middle East (about $10 \%$ ). The physicochemical properties of dust such as size distribution, composition, and shape vary substantially. Recent studies have shown that fine-mode dust has a cooling effect on the global climate, whereas coarse dust (particle diameter larger than $5 \mu \mathrm{m}$ ) likely has a warming impact (Kok et al., 2017; Miller et al., 2006). Mineral dust particles are characterized as nonspherical with irregular shapes and substantial surface heterogeneity (Wagner et al., 2012; Wiegner et al., 2009). Their optical properties, such as the lidar ratio, are also subject to their chemical composition. Therefore, dust particles originating from different regions exhibit different scattering properties due to their different microphysical and chemical composition (Järvinen et al., 2016; Müller et al., 2007; Nisantzi et al., 2015; Shin et al., 2018). Mineral dust and other aerosol particle types can affect clouds and their microphysical properties and precipitation patterns by acting as cloud condensation nuclei (CCN) and ice nuclei (IN) (DeMott et al., 2003; Karydis et al., 2011). To this end, numerous studies have identified the complex interplay of aerosols and clouds (Morrison et al., 2005; Rosenfeld, 2018). Li et al. (2017) report that dust-mixed ice clouds have warmer cloud top temperatures (CTTs), suggesting their efficiency in acting as IN. Most recent studies, however, stress the complexity of dust in the IN mechanism and its relative effectiveness in different geographic locations (Ansmann et al., 2009; Coopman et al., 2018; Filioglou et al., 2019; Zamora et al., 2017). The complexity of dust particles also becomes evident when comparing observations from remote sensing instruments with modelled dust properties (Binietoglou et al., 2015). Modelling the dust shape and further calculating its optical properties such as dust optical depth rely among others on approximations of the sphericity of the dust particles and assumptions about the contribution of non-dust particles together with vertical dust height information (Dubovik et al., 2002; Hoshyaripour et al., 2019). Accurate knowledge of the dust optical properties and their spatial distribution in regional and vertical scales is, therefore, a step towards a more realistic understanding of the climatic forcing impact of this component.

The Middle East and the Arabian Peninsula form one of the major source areas of mineral dust particles, together with northern Africa. Although this region is key to improving the understanding of the climate impact of mineral dust, very few measurement campaigns have been conducted and continuous aerosol observations are scarce in the area. In addition to being one of the world's largest sources of mineral dust, the Arabian Peninsula is also a large emitter of anthropogenic pollution (Rushdi et al., 2017). The United Arab Emirates (UAE) is a crossroad for air masses originating from western and central Asia or from northern Africa (Wehbe et al., 2017). Local emission of mineral dust is also abundant in this area. Regarding anthropogenic pollution, ever-growing energy demand has increased $\mathrm{CO}_{2}$ emissions and other pollutants of anthropogenic origin over the past decade (Betancourt-Torcat and Almansoori, 2015; Ukhov et al., 2018), with adverse health effects (Li et al., 2010). These varying aerosol sources make the UAE an interesting area to study aerosol particles, and, in particular, dust properties.

A few studies indicate that long-range transported dust from the Middle East exhibits different optical properties to that of Saharan origin (Hofer et al., 2017; Mamouri et al., 2013; Müller et al., 2007; Nisantzi et al., 2015). The lidar ratio is a parameter commonly used in lidar-based aerosol typing algorithms to classify the particles within an atmospheric layer (Nicolae et al., 2018; Papagiannopoulos et al., 2018). This parameter is also critical for elastic lidar retrievals and separation techniques (e.g. Giannakaki et al., 2020, and references therein). Within the European Aerosol Research Lidar Network (EARLINET, Pappalardo et al., 2014), stations are typically affected by dust outbreaks originating from the Saharan region. Amiridis et al. (2013) retrieved Saharan dust lidar ratios at $532 \mathrm{~nm}$ of $58 \pm 8 \mathrm{sr}$, while a mean (range) value considering all EARLINET stations is $51 \pm 10 \mathrm{sr}(30-80 \mathrm{sr})$, at the same wavelength (Papagiannopoulos et al., 2016). Currently, a mean value of $55 \mathrm{sr}$ is used for dust-related applications (e.g. Tesche et al., 2009). By contrast, the aerosol classification scheme from the satellite-based lidar onboard CALIPSO (Vaughan et al., 2009) uses a lidar ratio for pure dust of $44 \pm 9 \mathrm{sr}$ (Kim et al., 2018). Nevertheless, neither approach considers the origins of the dust, which translates into different optical characteristics.

To shed further light on atmospheric aerosol properties in the UAE region, a 1-year long field campaign was conducted from March 2018 to February 2019. The measurement campaign focused on the characterization of the geometrical and optical properties of atmospheric aerosol particles and their interaction with the regional/local meteorology and cloud precipitation patterns under different atmospheric conditions. With less than $100 \mathrm{~mm}$ of annual rainfall (Wehbe et al., 2017), precipitation enhancement techniques such as cloud seeding (French et al., 2018; Vonnegut and Chessin, 1971) have been implemented within the UAE's strategy for tackling water shortages in the region. This approach requires accurate understanding of local/regional meteorology, detailed characterization of the background aerosol particles and their efficiency in acting as CCN/IN, and the complex interplay between aerosol, clouds, and meteorology. Therefore, the Optimization of Aerosol Seeding In rain enhancement Strategies (OASIS) project aimed towards a more robust knowledge of the efficiency of the aerosol particles in acting as CCN/IN in a challenging environment. A multiinstrument approach was used for this purpose, including 
both in situ and remote sensing sensors along with model simulations. In this paper, we will focus on the characterization of the aerosol properties over the measurement site. Observations of a multi-wavelength Raman lidar with water vapour capability were used along with air mass backtrajectories calculated from the Hybrid Single Particle Lagrangian Integrated Trajectory (HySPLIT) model (Stein et al., 2015) in order to identify and classify the aerosol layers during the campaign period. Moreover, the optical properties of the Arabian Peninsula have been characterized.

\section{Methodology}

\subsection{The measurement site}

Between March 2018 and February 2019 the OASIS campaign was established at a palm plantation located $10 \mathrm{~km}$ south-west of Al Dhaid, in the emirate of Sharjah in the UAE $\left(25^{\circ} 14^{\prime} 7.8^{\prime \prime} \mathrm{N}, 55^{\circ} 58^{\prime} 39.97^{\prime \prime} \mathrm{E} ; 165 \mathrm{~m}\right.$ a.s.1). This rural site is located in a desert area about $70 \mathrm{~km}$ north-east from Dubai and the Arabian Gulf, where oil extraction and shipping activities are situated. To the east, the site faces a mountainous area whose altitude ranges from 1 to $2.1 \mathrm{~km}$ and the sea (Gulf of Oman and Arabian Sea, respectively) (Fig. 1a). In principle, the measurement site receives dust from three different sources. To the north, including Iraq and the surrounding countries, is a region with several sources of dust, and the sediment surface may contain sand deposits with particle sizes which are easily lofted by winds. In fact, it is the largest source of aeolian dust in the Arabian Gulf. Northeast in Iran and Pakistan are regions responsible for dust and sandstorms in Asia. Lastly, Saudi Arabia and the Arabian Peninsula provide the third major dust source with multiple terrain types. Towards the western side from the measurement location, mountains up to $2.5 \mathrm{~km}$ form a natural barrier between this region and the Red Sea. The region itself can be considered a fourth dust source where dust can be emitted locally due to thermal lows, unstable conditions, or human activities. Anthropogenic pollution is also present in the greater area, where oil and gas extraction activities add up to the man-made aerosol particulate burden from the cities. The aerosol optical depth (AOD) at $500 \mathrm{~nm}$ in the region varies between 0.4 and 0.5 (Eck et al., 2008), where the contribution of mineral dust particles can be $60 \%-70 \%$ even in urban areas (Roshan et al., 2019). Figure 1b shows the air mass backward trajectory cluster analysis, computed with HySPLIT (Stein et al., 2015; see Sect. 2.3), and their frequency over the course of the campaign period. The aforementioned aerosol sources can be viewed at the location of the backward trajectory paths.

\subsection{The multi-wavelength Raman lidar FMI-Polly}

The FMI-Polly ${ }^{\mathrm{XT}}$ lidar is a fully automated instrument capable of 24/7 operation (Engelmann et al., 2016). It is equipped with three elastic backscatter channels at 355, 532, and $1064 \mathrm{~nm}$, two rotational-vibrational Raman channels at 387 and $607 \mathrm{~nm}$, two linear depolarization channels at 355 and $532 \mathrm{~nm}$, and one water vapour detection channel at $407 \mathrm{~nm}$. In addition to the far-field capabilities, the system includes two near-field elastic backscatter channels at 355 and $532 \mathrm{~nm}$ and two near-field rotational-vibrational Raman channels at 387 and $607 \mathrm{~nm}$. Due to the near-field capability, full overlap is attained at around $120 \mathrm{~m}$. Data are acquired with a vertical resolution of $7.5 \mathrm{~m}$ in temporal steps of $30 \mathrm{~s}$.

The lidar has been employed under various campaigns and locations over the course of years. Among others, two longterm aerosol experimental campaigns at Gual Pahari, India (Komppula et al., 2012), and Elandsfontein, South Africa (Giannakaki et al., 2015, 2016; Korhonen et al., 2014), and at the permanent measurement site in Vehmasmäki, Finland (Bohlmann et al., 2019; Filioglou et al., 2017), have been conducted. The system is also part of the Finnish lidar network (Hirsikko et al., 2014), EARLINET (Bösenberg et al., 2003; Pappalardo et al., 2014), and PollyNET (Baars et al., 2016), which is an independent Raman and polarization lidar network where measurements from all member stations are visualized through "quick looks", publicly available on the web page of PollyNET (http://polly.tropos.de, last access: 22 July 2020).

\subsection{Processing of lidar observations}

For the analysis presented, two aerosol profiles were retrieved per day using the Raman method (Ansmann et al., 1990, 1992; Whiteman, 2003) at 01:00 and 20:00 UTC in order to derive all possible optical properties minimizing the assumptions in the retrievals. The $2 \mathrm{~h}$ average profiles were further processed by detecting intensive aerosol layers and isolating them from air segments containing very low aerosol particle burden. We should note here that, at this point, cloudcontaminated height bins were already excluded from the signal. For the automatic detection of the aerosol particle layers we used the second derivative of the backscatter profiles at $1064 \mathrm{~nm}$. Detected aerosol layers with geometrical depths less than $50 \mathrm{~m}$ were discarded. In total 1130 high-quality aerosol particle layers were detected during the campaign period. We considered high-quality aerosol layers to be the ones which (a) were not affected by clouds, (b) exhibited lidar ratios between 5 and $150 \mathrm{sr}$, (c) had a linear particle depolarization ratio between $0 \%$ and $40 \%$, and (d) had Ångström exponents between -1.1 and 3 . The geometrical boundaries of the aerosol particle layers were retrieved from a less vertically smoothed lidar profile (less than $400 \mathrm{~m}$ ), as opposed to the optical properties, which were retrieved by applying higher smoothing (case-dependent). By applying less smoothing to the signals, we were able to appoint correct geometrical depths and boundaries of these layers, while the higher smoothing assigned meaningful optical properties. Mean values of all the available optical properties, i.e. backscatter $(\beta)$ 

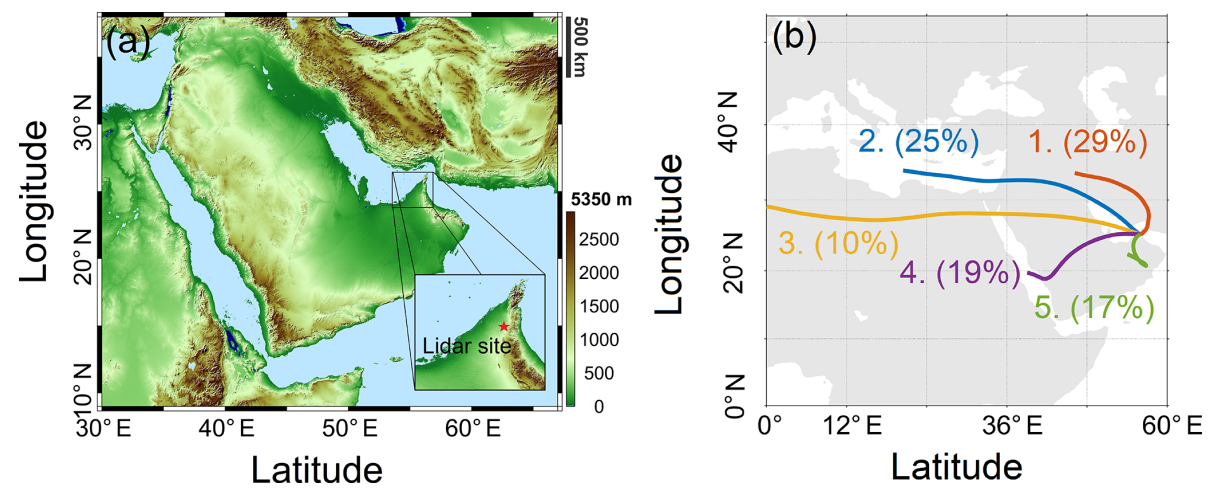

Figure 1. (a) Digital elevation map (DEM) from the NASA Shuttle Radar Topographic Mission (SRTM) for the greater area under study. The colour bar values correspond to the altitude above sea level. The site location is shown in the bottom right of this figure with a red star. (b) Cluster analysis of sources of the detected night-time aerosol layer in the region computed with HySPLIT over the course of the campaign period. Coloured lines indicate the trajectory path and the numbers show the percentage share of each trajectory path.

and extinction $(\alpha)$ coefficients, lidar ratios (LRs), Ångström exponents (AE for the extinction-related and BAE for the backscatter-related Ångströms), colour ratios (CRs), linear particle depolarization ratios $\left(\delta_{\mathrm{p}}\right)$, and AODs, were then calculated for each of the layers, along with their geometrical properties (depth and centre mass). For the mean optical properties, only regions where the extensive aerosol properties (backscatter and extinction coefficients) were nearly constant were considered. This means that within the defined layer, the variability of the optical properties should be less than the statistical uncertainty of the individual data points. On top of that, aerosol layers were further eliminated if minimum backscatter thresholds were not met $(0.25,0.10$, and $0.05 \mathrm{Mm}^{-1} \mathrm{sr}^{-1}$ for 355,532 , and $1064 \mathrm{~nm}$, respectively) A $5 \mathrm{~d}$ backward trajectory analysis at the centre mass of each of the aerosol layers was also computed using HySPLIT in order to assess the origin of the detected aerosol particle layers. The timestamp used for the trajectories was the centred $2 \mathrm{~h}$ lidar retrieval.

\subsection{Microanalysis of the collected dust particles}

To aid the findings in Sect. 3.3 where we retrieve the optical properties of the Arabian dust particles, we have collected two soil samples from the surrounding region. The samples were dry collected, accounting for both microphysical (colour of the soil) and regional discrepancies; one sample was close to the observation site and the other one a few tens of kilometres away. Two particle distributions were studied to reveal physicochemical properties of gathered particles, i.e. size, morphology, and composition. In order to analyse the chemical composition of the particles, energy dispersive X-ray spectroscopy (EDX, Thermo Pathfinder 1.4, Thermo Fisher Scientific, Madison, WI, USA) was used in synergy with a scanning electron microscope (SEM, Zeiss SigmaHDIVP, Carl Zeiss NTS, Cambridge, UK) which was used to observe the morphology of the dust particles. For this,

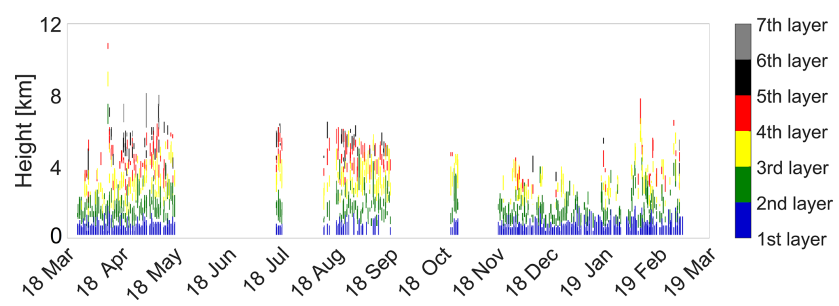

Figure 2. Night-time geometrical boundaries of the aerosol layers observed between 6 March 2018 and 14 February 2019 at the measurement site in the UAE. The colour indicates the number of aerosol layers in the atmosphere. The gaps in the dataset seen from May to August and between September and November were due to instrumental complications.

dust samples were attached on a standard $12 \mathrm{~mm}$ aluminium stub for SEM specimens using a piece of double-sided carbon adhesive tape. The SEM imaging was executed without any sputter coating in a low-vacuum (Zeiss Variable Pressure mode) nitrogen atmosphere at $30 \mathrm{~Pa}$ pressure using $15 \mathrm{kV}$ acceleration voltage, a variable pressure secondary electron (VPSE) detector, and a working distance of $15 \mathrm{~mm}$. The elemental composition for individual particles was obtained using EDX mapping. The chemical analysis and two SEM images can be found in Appendix A.

\section{Results}

\subsection{Geometrical properties and aerosol optical depths of aerosol particle layers}

Altogether 1130 night-time aerosol particle layers were analysed throughout the campaign period in order to characterize the background aerosol properties over the measurement site. The time series of the geometrical extent of the retrieved aerosol particle layers showed up to seven simultaneous lay- 


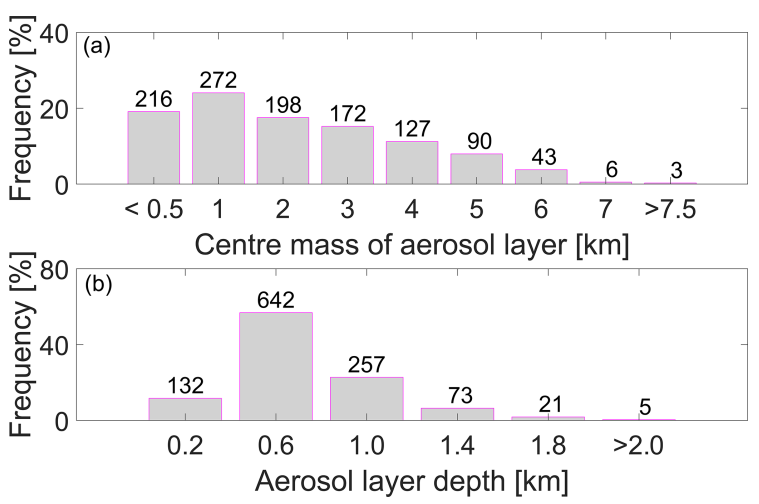

Figure 3. Geometrical characteristics of the aerosol layers during the campaign period. (a) Frequency of the altitude of the centre of mass of the aerosol layers. The width of each bin $1 \mathrm{~km}$ apart from the first and last bins. (b) Frequency of the geometrical depth of the aerosol layers. The width of each bin is $0.4 \mathrm{~km}$ apart from the last bin. The numbers on top of the bars indicate the number of cases included in the bin.

ers (Fig. 2). Indeed, as observed in the dataset, frequent multiple aerosol particle layer structures were present most of the time, with single layers mostly occurring during December and January. In fact, only $10 \%$ of the cases had a single aerosol layer present, with two (30\%), three (29\%), or even more simultaneous layers $(31 \%)$. The multiple aerosol particle layers result from gravitational waves generated by the sea breeze passing over the mountains, stratifying the atmosphere over the measurement site. The gaps in the dataset during May to August and between September and November were due to instrumental malfunction, mainly failure of the cooling unit of the system while performing under such demanding conditions where maximum ambient temperatures up to $51{ }^{\circ} \mathrm{C}$ were measured.

Geometrical features of the aerosol particle layers are further characterized by frequency distributions (Fig. 3). Up to $61 \%$ of the layers identified were located below $2.5 \mathrm{~km}$ in altitude, with a few layers reaching as high as $11 \mathrm{~km}$. The geometrical depths of the layers varied from a few hundred metres to several kilometres throughout the period. Most commonly ( $58 \%$ of the cases) the geometrical depth varied between 0.4 and $0.8 \mathrm{~m}$.

In order to define the geometrical boundaries of the aerosol particle layers in the free troposphere (FT) and the planetary boundary layer (BL), we determined the top height of the BL using the methodology described in Baars et al. (2008). The night-time $\mathrm{BL}$ over the measurement site ranged between 0.35 and $1.2 \mathrm{~km}$, while the mean top of the mixed layer height during daytime was at $2.0 \pm 0.3 \mathrm{~km}$ (not shown here). It should be noted that the observed night-time lidar BL height is expected to depict, apart from any mechanically driven layer during the stable and transition periods, the top of the residual layer from the previous day. The rather low in altitude, daytime BL is suppressed by several limiting

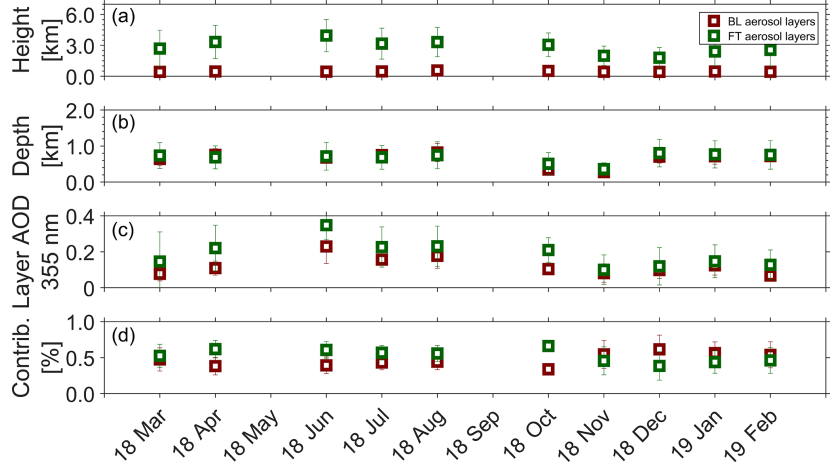

Figure 4. Geometrical characteristics and optical properties of the detected night-time aerosol layers located in the boundary layer (BL aerosol layers; in red) and free troposphere (FT aerosol layers; in green). (a) Centre of mass height of the aerosol layers. (b) Geometrical depth of the detected layers. (c) Layer aerosol optical depths (AODs) at 355. (d) Contribution of BL (red) and FT (green) aerosol layers to the total AOD.

factors: (1) the frequent high-pressure system in the region, (2) gravitational waves, (3) low wind speeds, and (4) very dry air, which altogether limit convection. The gravitational waves define the horizontal transport of air and limit the growth of the BL to higher altitudes. In total, $844 \mathrm{FT}$ aerosol particle layers were observed, and 286 BL layers. To have a better insight into the time variation of the aerosol particle layers, Fig. 4 presents the monthly geometrical and aerosol optical depth characteristics of aerosol layers located at the BL and FT. Figure $4 \mathrm{a}$ corresponds to the centre of mass of the detected aerosol layers at the BL (red) and FT (green). While there is a very persistent night-time BL with a top height at $1 \mathrm{~km}$ or so throughout the measurement year, the aerosol layers located at the FT show seasonality. The FT aerosol particle layers extend to higher altitudes during the warmer months (April-August) and have a minimum height during November-December. Regarding their average geometrical depth (Fig. 4b), both BL and FT aerosol layers exhibit similar characteristics. The geometrical depth is calculated from the aerosol layer boundaries (top/bottom) in which the subtraction of these boundaries results in the actual geometrical thickness of the corresponding aerosol layers.

The optical depths of BL and FT aerosol layers at $355 \mathrm{~nm}$ wavelength and their contribution to the total layer AOD are shown in Fig. 4c-d. Similar conclusions are valid for AOD at the $532 \mathrm{~nm}$ wavelength, which is not shown here but is discussed in the paper. The optical depths were determined by integrating the layer aerosol extinction coefficient at 355 and $532 \mathrm{~nm}$. For the first layer, where the overlap is incomplete, we assumed that the extinction coefficient value at the lowest trustworthy bin is representative for the values down to the surface to account for the incomplete overlap region. The highest-layer AODs were measured during the summer months and the lowest values during November and 


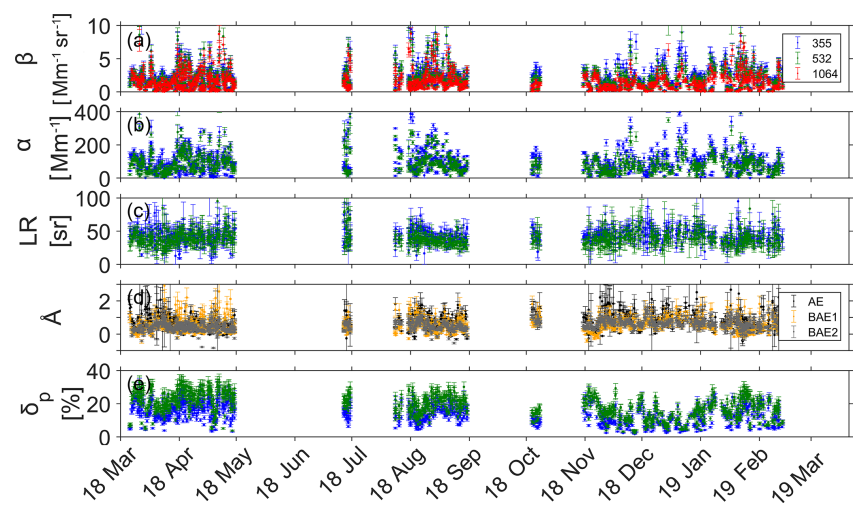

Figure 5. Time series of intensive and extensive aerosol properties at different wavelengths $(355 \mathrm{~nm}$ in blue, $532 \mathrm{~nm}$ in green, and $1064 \mathrm{~nm}$ in red). (a) Backscatter coefficient. (b) Extinction coefficient. (c) Lidar ratio. (d) Ångström exponents ( $\mathrm{A})$ where the extinction-related Ångström exponent (AE) is marked with black dots, the backscatter-related Ångström exponent at 355/532 (BAE1) with orange, and the backscatter-related Ångström exponent at 532/1064 (BAE2) with grey. (e) Linear particle depolarization ratio $\left(\delta_{\mathrm{p}}\right)$. The values show the mean optical property of the aerosol layer along with 1 standard deviation indicated with the error bars.

December for FT aerosol layers and February for BL aerosol layers. The mean (maximum) value of the total layer AOD amounts to $0.37 \pm 0.12(1.11)$ and $0.21 \pm 0.11(1.04)$ at 355 and $532 \mathrm{~nm}$, respectively. These values are in line with previous studies utilizing mainly sunphotometric observations in inland desert areas in the surrounding region (Ali et al., 2017; Eck et al., 2008). Moderate variations of the contribution of AOD in FT to the total layer AOD were observed for the investigated period (Fig. 4d). The contribution of the nighttime FT layers to the total AOD was usually greater than that of the BL. Nevertheless, this behaviour was reversed from November to February. The lower total layer AODs in these months may be attributable to the absence of multiple FT layers or to the lower surface wind speeds (which drive dust particles) during those months. There is a mesoscale phenomenon referred to as shamal conditions where northerly to north-westerly winds are more intense between March and August compared to the rest of the year (Kutiel and Furman, 2003; Yu et al., 2016).

\subsection{Intensive and extensive aerosol properties}

So far, we have examined the monthly variation of the aerosol layers over the measurement site in terms of their geometrical and AOD properties. In this section, we investigate the intensive (lidar ratios, linear particle depolarization ratios, and Ångström exponents) and extensive (backscatter and extinction coefficients) aerosol properties of the retrieved aerosol particle layers (Fig. 5). Figure 5 shows the time series of mean optical properties along with 1 standard deviation. Note that the marking of the month in the $x$ axis in Fig. 5 cor-
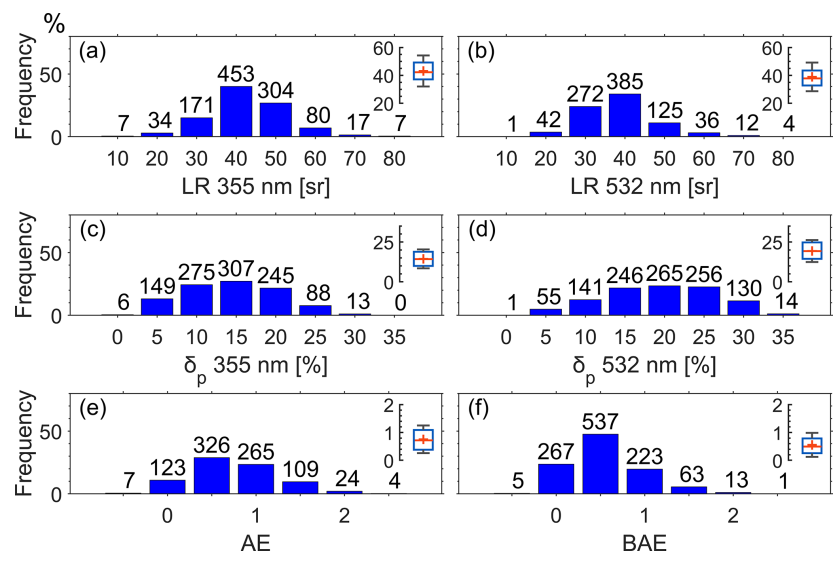

Figure 6. Frequency distribution of (a) lidar ratio at $355 \mathrm{~nm}$ with bin width of $10 \mathrm{sr}$. (b) Lidar ratio at $532 \mathrm{~nm}$ with bin width of $10 \mathrm{sr}$. (c) Linear particle depolarization ratio at $355 \mathrm{~nm}$ with bin width of $5 \%$. (d) Linear particle depolarization ratio at $532 \mathrm{~nm}$ with bin width of $5 \%$. (e) Extinction-related Ångström exponent (AE) at 355/532 with bin width of 0.5. (f) Backscatter-related Ångström exponent (BAE) at 355/532 with bin width of 0.5. Box and whisker plots are also presented, where the cross is the mean value, the horizontal line is the median, boxes are the 25th and 75th percentiles, respectively, and whiskers represent the 1 standard deviation. The numbers above the bars indicate the number of cases fallen in the bin.

responds to the first day of that month. The backscatter and extinction coefficient values indicate occasional strong dust events. The dust events take place mainly between March and August when enhanced shamal conditions cause an increase in the probability of dust suspension and dust storms (Yu et al., 2016). Average $\beta$ values of $2.5 \pm 1.9,2.1 \pm 1.9$, and $1.6 \pm 1.6 \mathrm{Mm}^{-1} \mathrm{sr}^{-1}$ for 355,532 , and $1064 \mathrm{~nm}$ were observed, respectively. During strong dust events $\beta$ values up to $19.7(18.5,16.4) \mathrm{Mm}^{-1} \mathrm{sr}^{-1}$ at $355(532,1064) \mathrm{nm}$ and $\alpha$ values of 800 (774) $\mathrm{Mm}^{-1}$ at 355 (532) nm were measured (not shown in the figure). In general, the intensive optical properties exhibit similar characteristics with little variation throughout the year apart from the period from midNovember to January. During the winter season increased LR values related to bigger Ångström exponents and lower linear particle depolarization values indicate a greater share of anthropogenic pollution in the aerosol particle mixture compared to other seasons.

Histograms of the aforementioned optical properties are shown in Fig. 6. In the same figure, the statistical distribution is also presented with box and whisker plots. For 40 (35) \% of the cases, the LR at 355 (532) nm ranged between 35 and $45 \mathrm{sr}$, while the second most frequent LR range was 45-55 (25-35) sr for 355 (532) nm, representing 27 (25) \% of the cases. Furthermore, less than $12 \%$ of the cases exhibited $\delta_{\mathrm{p}} \geq 27 \%$, indicating the complexity of the aerosol type over the site, frequently a mixture of mineral dust (dominant aerosol) with anthropogenic and/or marine aerosol presence. This is also consistent with the backscatter-related Ångström 


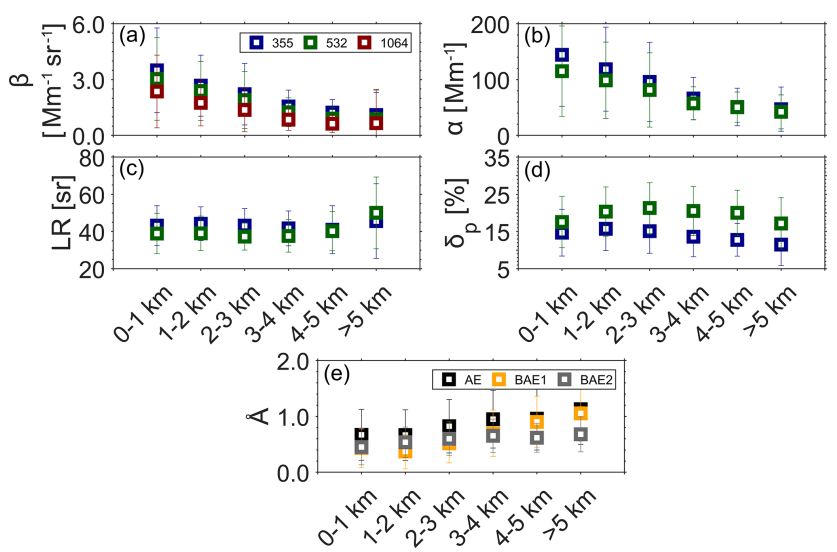

Figure 7. Height-dependent aerosol properties for $0-1,1-2,2-$ $3,3-4$, and $>5 \mathrm{~km}$ altitude. (a) Backscatter coefficient at $355 \mathrm{~nm}$ (blue), $532 \mathrm{~nm}$ (green), and $1064 \mathrm{~nm}$ (red). (b) Extinction coefficient at $355 \mathrm{~nm}$ and $532 \mathrm{~nm}$. (c) Lidar ratio at $355 \mathrm{~nm}$ and $532 \mathrm{~nm}$. (d) Linear particle depolarization ratio at $355 \mathrm{~nm}$ and $532 \mathrm{~nm}$. (e) Extinction-related Ångström exponent (AE) at 355/532, backscatter-related Ångström exponent (BAE1) at 355/532, and backscatter-related Ångström exponent (BAE2) at 532/1064.

exponent staying well below 0.8 in $71 \%$ of the cases. In general, average LRs of $43 \pm 11$ and $39 \pm 10$ sr were observed at 355 and $532 \mathrm{~nm}$, respectively. The mean $\delta_{\mathrm{p}}$ was $15 \pm 6 \%$ for the $355 \mathrm{~nm}$ wavelength and $19 \pm 7 \%$ at $532 \mathrm{~nm}$. A mean extinction-related Ångström exponent of $0.7 \pm 0.5$ between 355 and $532 \mathrm{~nm}$ was measured during the 1-year period in the UAE, similar to the value by Eck et al. (2008) based on sunphotometric observations in the greater area. Lastly, backscatter-related Ångström exponents at 355/532 and 532/1064 (not shown) were $0.6 \pm 0.4$ and $0.5 \pm 0.3$, respectively.

In order to reveal height-dependent aerosol particle properties, we have further divided the atmosphere into five altitude ranges $(0-1,1-2,2-3,3-4$, and $>5 \mathrm{~km})$ and grouped the aerosol properties contained in each altitude segment (Fig. 7). As expected, the $\beta$ and $\alpha$ coefficients decreased with increasing altitude. In contrast, LRs showed rather constant behaviour up to $5 \mathrm{~km}$, suggesting similar aerosol mixtures throughout these altitude ranges. Interestingly, $\delta_{\mathrm{p}}$ at $532 \mathrm{~nm}$ wavelength increased or remained constant with altitude except for aerosol layers above $5 \mathrm{~km}$. This behaviour was seen at $355 \mathrm{~nm}$ wavelength up to $2 \mathrm{~km}$, but $\delta_{\mathrm{p}}$ then decreased with altitude above $2 \mathrm{~km}$. The most plausible explanation is that up to $2 \mathrm{~km}$ or so the night-time residual layers contain mixtures of mineral dust and anthropogenic pollution or/and marine aerosols resulting in lower linear particle depolarization values. The mean relative humidity of these aerosol layers is much less than $60 \%$ for $82 \%$ of the cases; hence, hygroscopicity effects can be excluded. Ångström exponents increasing with altitude show the height-dependent nature of the aerosol
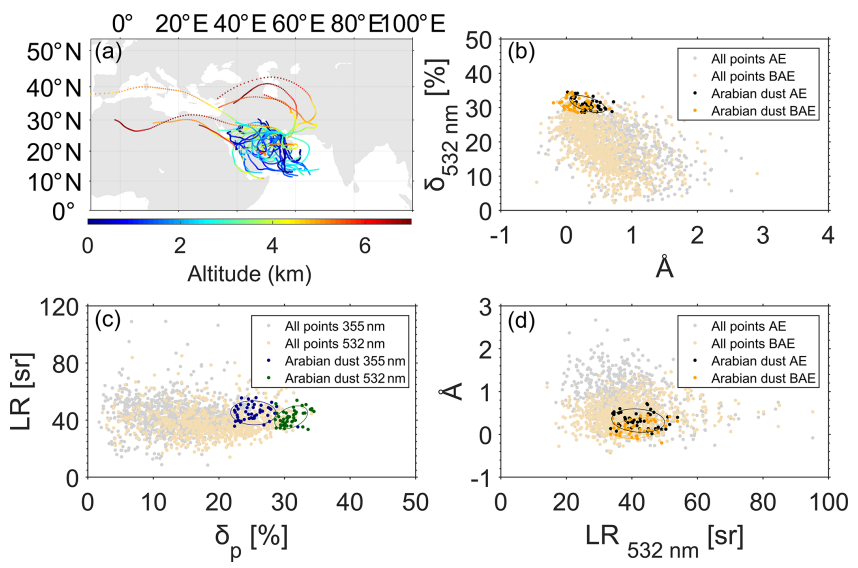

Figure 8. (a) Backward air mass trajectories of all the cases considered for the characterization of the Arabian dust properties. (b) Ångström exponent $(\AA)$ versus linear particle depolarization $\left(\delta_{\mathrm{p}}\right)$ at $532 \mathrm{~nm}$. (c) Linear particle depolarization $\left(\delta_{\mathrm{p}}\right)$ versus lidar ratio (LR). (d) Lidar ratio (LR) at $532 \mathrm{~nm}$ versus Ångström exponents ( $\mathrm{A})$. The Ångström exponent plots at (b) and (d) indicate the extinction-related (AE) and backscatter-related (BAE) exponents at 355/532. The ellipsoids in panels (b)-(d) were drawn considering a $95 \%$ confidence for the set of data points.

size distribution (the higher the altitude, the smaller the particles).

\subsection{Optical properties of Arabian dust}

To characterize the properties of mineral dust over the region, we have selected the top decile of linear particle depolarization values in the dataset. We discarded cases when the path of a backward air mass trajectory passed over regions other than the Arabian Peninsula and the minimum height of the air mass over these regions was less than $3 \mathrm{~km}$ in altitude. The backward trajectories of the selected 46 cases are shown in Fig. 8a and the characteristic optical properties and the aerosol type-dependent optical properties in Fig. 8b-d for both 355 and $532 \mathrm{~nm}$ wavelengths, including $95 \%$ confidence ellipsoids. Figure $8 \mathrm{~b}-\mathrm{d}$ also present the rest of the available aerosol layer optical properties apart from the ones defined as Arabian dust. We assume that cases with the highest linear depolarization ratios represent the pure Arabian dust optical properties since no volcanic aerosols are present over the measurement site at the given period. It is also evident from the scatter plots that the aerosol sources and types are varying; thus, no detailed conclusions can be made for the full dataset except the ones mentioned in previous sections. The mean values of the Arabian dust optical properties are further reported in Table 1 along with literature values. The mean altitude of these layers was $1.8 \pm 0.9 \mathrm{~km}$; in $73 \%$ of the cases the centre mass of the layer was located above $1 \mathrm{~km}$, excluding the one well-mixed with anthropogenic or/and marine pollution night-time BL. The retrieved dust aerosol properties over the region concerning the 
Table 1. Aerosol particle properties of the Arabian dust and comparison to previous studies. Both 355 and $532 \mathrm{~nm}$ wavelengths are reported in terms of their lidar ratio (LR), linear particle depolarization $\left(\delta_{\mathrm{p}}\right)$, and the ratio of their lidar ratios. Combinations of Ångström exponents from both the extinction (AE) and backscatter (BAE) coefficients along with the colour ratios (CRs) are shown due to the multi-wavelength capability of the lidar instrument. The numbers in the brackets show the range of values found for each optical property.

\begin{tabular}{|c|c|c|c|c|c|c|c|c|c|c|c|}
\hline Property & $\begin{array}{r}\text { LR } \\
355 \mathrm{~nm} \\
{[\mathrm{sr}]}\end{array}$ & $\begin{array}{r}\text { LR } \\
532 \mathrm{~nm} \\
{[\mathrm{sr}]}\end{array}$ & $\begin{array}{r}\delta_{\mathrm{p}} \\
355 \mathrm{~nm} \\
{[\%]}\end{array}$ & $\begin{array}{r}\delta_{\mathrm{p}} \\
532 \mathrm{~nm} \\
{[\%]}\end{array}$ & $\begin{array}{r}\mathrm{AE} \\
355 / \\
532 \\
\end{array}$ & $\begin{array}{r}\text { BAE } \\
355 / \\
532 \\
\end{array}$ & $\begin{array}{c}\text { BAE } \\
532 / \\
1064 \\
\end{array}$ & $\begin{array}{r}\text { CR } \\
355 / \\
1064 \\
\end{array}$ & $\begin{array}{r}\text { CR } \\
532 / \\
1064 \\
\end{array}$ & $\begin{array}{r}\text { CR } \\
355 / \\
532 \\
\end{array}$ & $\begin{array}{r}\text { LR355/ } \\
\text { LR532 }\end{array}$ \\
\hline $\begin{array}{l}\text { Müller et } \\
\text { al. (2007) }\end{array}$ & $38 \pm 5$ & $38 \pm 5$ & - & - & $0.6 \pm 0.3$ & - & $1.1 \pm 0.4$ & - & - & - & $\sim 1$ \\
\hline $\begin{array}{l}\text { Mamouri } \\
\text { et al. } \\
(2013)\end{array}$ & - & $\begin{array}{r}34 \pm 7 \\
\text { to } 39 \pm 5\end{array}$ & - & $\begin{array}{r}- \\
(28-35)\end{array}$ & - & - & - & - & - & - & - \\
\hline $\begin{array}{l}\text { Nisantzi } \\
\text { et al. } \\
(2015)\end{array}$ & - & $\begin{array}{r}41 \pm 4 \\
(33-48)\end{array}$ & - & - & - & - & - & - & - & - & - \\
\hline $\begin{array}{l}\text { Hofer et } \\
\text { al. (2017) }\end{array}$ & $42 \pm 3$ & $36 \pm 2$ & $18 \pm 2$ & $31 \pm 1$ & $0.4 \pm 0.2$ & $0.0 \pm 0.2$ & $0.1 \pm 0.0$ & - & - & - & - \\
\hline $\begin{array}{l}\text { This } \\
\text { study }\end{array}$ & $\begin{array}{r}45 \pm 5 \\
(35-55)\end{array}$ & $\begin{array}{r}42 \pm 5 \\
(34-54)\end{array}$ & $\begin{array}{r}25 \pm 2 \\
(22-32)\end{array}$ & $\begin{array}{r}31 \pm 2 \\
(28-35)\end{array}$ & $\begin{array}{l}0.3 \pm 0.2 \\
(0.0-0.7)\end{array}$ & $\begin{array}{r}0.2 \pm 0.2 \\
(-0.2-0.7)\end{array}$ & $\begin{array}{l}0.3 \pm 0.1 \\
(0.1-0.6)\end{array}$ & $\begin{array}{l}1.4 \pm 0.2 \\
(1.1-2.0)\end{array}$ & $\begin{array}{l}1.3 \pm 0.1 \\
(1.1-1.5)\end{array}$ & $\begin{array}{l}1.1 \pm 0.1 \\
(0.9-1.3)\end{array}$ & $\begin{array}{l}1.1 \pm 0.1 \\
(0.9-1.3)\end{array}$ \\
\hline
\end{tabular}

lidar ratios fluctuated between 35(34) and 55(54) sr with a mean value of $45 \pm 5(42 \pm 5)$ sr at $355(532) \mathrm{nm}$. The values ranged between $22(29)$ and $32(35) \%$ with an average value of $25 \pm 2(31 \pm 2) \%$ for the linear particle depolarization ratio at $355(532) \mathrm{nm}$ and $0.3 \pm 0.2(0.2 \pm 0.2,0.3 \pm 0.1)$ for the extinction-related Ångström exponent (backscatterrelated Ångström exponent at 355/532 and 532/1064). The ratio of LRs fluctuated between 1.0 and 1.2. Moreover, we report on the ratio of backscatter coefficients known as the colour ratio (CR) between the 355/523, 355/1064, and 532/1064 wavelengths. This ratio is usually below 1 for aerosols and can be used in a simple aerosol/cloud detection scheme, but dust particles show ratios above 1, which complicates this rather simple and straightforward relationship. Note that in the literature the CR is retrieved interchangeably either from bigger to smaller wavelength or the opposite. In this paper we calculated the CR as smaller to bigger wavelength; therefore, the expected values are above 1 . All in all, the Arabian dust optical properties show close to 0 Ångström exponents and high linear depolarization ratios, characteristics that are similar to Saharan dust. Dissimilarly, Arabian dust has lower LRs, and these LRs are almost equal at 355 and $532 \mathrm{~nm}$. Another difference is the CRs, which are well above 1, ranging from 1.1 up to 2.0 depending on the wavelength selection.

To the authors' knowledge, four earlier studies have attempted to characterize the properties of dust originating from the Arabian Peninsula using the lidar technique; however, the full properties of dust were not characterized, and particularly multi-wavelength optical properties and/or linear particle depolarization values have not been simultaneously defined. Müller et al. (2007), using lidar observations during INDOEX (Indian Ocean Experiment, Ramanathan et al., 2001), were the first to stress the lower LR values of free-tropospheric dust when originating from the Arabian Peninsula compared to that from the northern Sahara. However, the long-range transported Arabian dust (aged) in their study suggests smaller LR values and greater Angström exponents than the ones reported here (Table 1). Similar conclusions were found by Mamouri et al. (2013) and Nisantzi et al. (2015), whose studies show a lower LR for the Arabian dust over a Mediterranean site in Cyprus than dust originating from the Saharan area, based on study cases (Table 1). A recent study by Hofer et al. (2017) using lidar observations in Tajikistan, central Asia, also reports on Middle East dust optical properties and comparisons of those to Asian dust. In the same direction, the study cases used over Dushanbe in Tajikistan show similar Arabian dust characteristics to those in the present study (see Table 1).

A few limited studies are also available for the characterization of the Arabian dust properties using sunphotometric observations. Sunphotometric observations are columnintegrated values which often include the contribution of BL aerosols and the contribution of non-dust aerosols (smoke, marine and anthropogenic aerosols). Nevertheless, Schuster et al. (2012) report a mean LR of $43 \mathrm{sr}$ at $532 \mathrm{~nm}$ with a 39 to 43 sr range. By contrast, Shin et al. (2018) result in higher LR values such as $54 \pm 7 \mathrm{sr}$ at $440 \mathrm{~nm}$ and $37 \pm 4 \mathrm{sr}$ at $670 \mathrm{~nm}$. The reported linear particle depolarization ratios are $0.21 \pm 0.03 \%$ at $440 \mathrm{~nm}$ and $0.25 \pm 0.03 \%$ at $670 \mathrm{~nm}$, whereas the Ångström exponent is $0.18 \pm 0.10$ at $440 / 870 \mathrm{~nm}$.

Examining the reasons behind the different LR values in Arabian compared to African dust, previous studies related the optical characteristics to the chemical composition of the dust particles themselves. Numerous studies have analysed 
samples from various regions exploring the mineralogical composition of dust (Di Biagio et al., 2017; Egan and Hilgeman, 1979; Querry, 1987; Sokolik and Toon, 1999). Schuster et al. (2012) linked the LR behaviour of dust to the percentage of illite in the soil. Clay minerals and specifically the content of illite (a K-rich argillaceous component of sedimentary rocks) in the dust define the real refractive index which strongly influences LR. Since the real refractive index, which is determined by the mineralogical composition of dust, defines the lidar ratio, an aerosol-type parameter, it is expected that different dust types would exhibit different optical characteristics. Lower content of illite signifies lower LR compared to, for example, higher content of illite in Saharan soils, which results in the somewhat higher real refractive index. The real refractive index of dust from the Arabian Peninsula is 1.50 and for Saharan dust the corresponding value is 1.54 (Di Biagio et al., 2017; Kim et al., 2011; Schuster et al., 2012). Moreover, the study of Di Biagio et al. (2019) reports that the imaginary part of the refractive index in dust samples originating from Saudi Arabia scores less than that of African dust, presenting a lower absorbing efficiency compared to African dust. The difference is attributed to the content of iron oxides in the dust. In this direction, we have collected two different dust samples from the area around the measurement site and further retrieved SEM images and performed elemental analysis (see Appendix A). Comparable to previous studies mentioned above, the fraction of a K-rich argillaceous component of sedimentary rocks was well below $5.5 \%$ in the collected dust samples. Regarding the absorption properties of dust, it has been found that dust optical properties are more correlated with the fraction of iron oxides than the iron content itself. Nevertheless, the iron content in the collected dust samples was lower than that recorded in African dust (Di Biagio et al., 2019).

\section{Summary and conclusions}

One year of ground-based night-time lidar observations was analysed in synergy with backward air mass trajectories in order to characterize the seasonal variability of the background aerosol particle properties in a - heavy dust and anthropogenic polluted - region in the United Arab Emirates (UAE). Our analysis suggests that aerosol particle populations over the UAE are sensitive to transport from Saudi Arabia, Iran, and Iraq but also from local sources. Two seasons exist in this area, summer and winter, where the main difference is the higher wind speeds between March and August compared to the rest of the year. The AOD was positively correlated with the season, with maximum values being observed in the warmest months, June to August, resulting from the increased probability of dust suspension and dust storms. Multiple aerosol layers were present in the majority of identified cases, except during November-December; for $58 \%$ of the cases the geometrical depth ranged between
0.4 and $0.8 \mathrm{~km}$. The geometrical properties are determined by large-scale pressure systems over the region as well as gravitational waves introduced by local and regional topography. Regarding the optical properties, Ångström exponent values increased with altitude, indicating the incapacity of bigger aerosols to reach higher up in the atmosphere. Lidar ratios were almost constant up to $5 \mathrm{~km}$, with mean values of $43 \pm 11 \mathrm{sr}$ at $355 \mathrm{~nm}$ and $39 \pm 10 \mathrm{sr}$ at $532 \mathrm{~nm}$. The linear particle depolarization, $\delta_{\mathrm{p}}$, at $532 \mathrm{~nm}(355 \mathrm{~nm})$, however, increased with altitude up to $3 \mathrm{~km}(2 \mathrm{~km})$. The most probable explanation is that up to $2 \mathrm{~km}$ or so, night-time residual layers contain mixtures of mineral dust and urban-marine aerosols resulting in lower linear particle depolarization values. Higher up the linear particle depolarization decreases; the aerosol particles at higher altitudes are usually long-range transported, and while aging in the atmosphere they become more spherical.

The Arabian Peninsula is a major contributor of airborne dust, yet very few studies have been made in order to characterize the pure dust optical properties of the region. To our knowledge this study is the first long-term one reporting the complete lidar-based optical characteristics of the Arabian dust. The FMI-Polly ${ }^{\mathrm{XT}}$ Raman lidar enabled the provision of lidar ratios and linear particle depolarization ratios at two wavelengths $(355,532 \mathrm{~nm})$, giving us the possibility of an answer to wavelength-dependent dust properties. The observed dust particle properties over the region regarding the lidar ratio amounted to $45 \pm 5 \mathrm{sr}$ at $355 \mathrm{~nm}$ and $42 \pm 5 \mathrm{sr}$ at $532 \mathrm{~nm}$ wavelength. Linear particle depolarization ratios of $25 \pm 2 \%(31 \pm 2 \%)$ were observed at $355(532) \mathrm{nm}$, and $0.3 \pm 0.2(0.2 \pm 0.2)$ values were retrieved for the extinctionrelated Ångström exponent (backscatter-related Ångström exponent) at 355/532. The findings of this study suggest that the pure dust properties over the Middle East and western Asia, including the observation site, are comparable to those of African mineral dust regarding the linear particle depolarization ratios, but not for the lidar ratios. The lower lidar ratio values are attributed to the different geochemical characteristics of soil, with Arabian dust having lower K-rich values in the dust mixture, a component which determines the real refractive index of the dust and lower absorbing efficiency than that of Saharan dust which is attributed to the iron content. These findings propose that the use of a lidar ratio value for dust aerosol particles should consider the origin of the dust itself, otherwise biased results can be anticipated, for example in satellite or ground-based extinction and aerosol typing retrievals as well as separation methods of a lidar signal into its aerosol components. This becomes evident in stations where they are receptors of both Arabian and Saharan dust and the selection of adequate dust optical parameters is important for further analysis. In turn, all the aforementioned products are usually the basic input for advanced methodologies such as the retrieval of CCN/IN concentrations from lidar observations. 


\section{Appendix A}

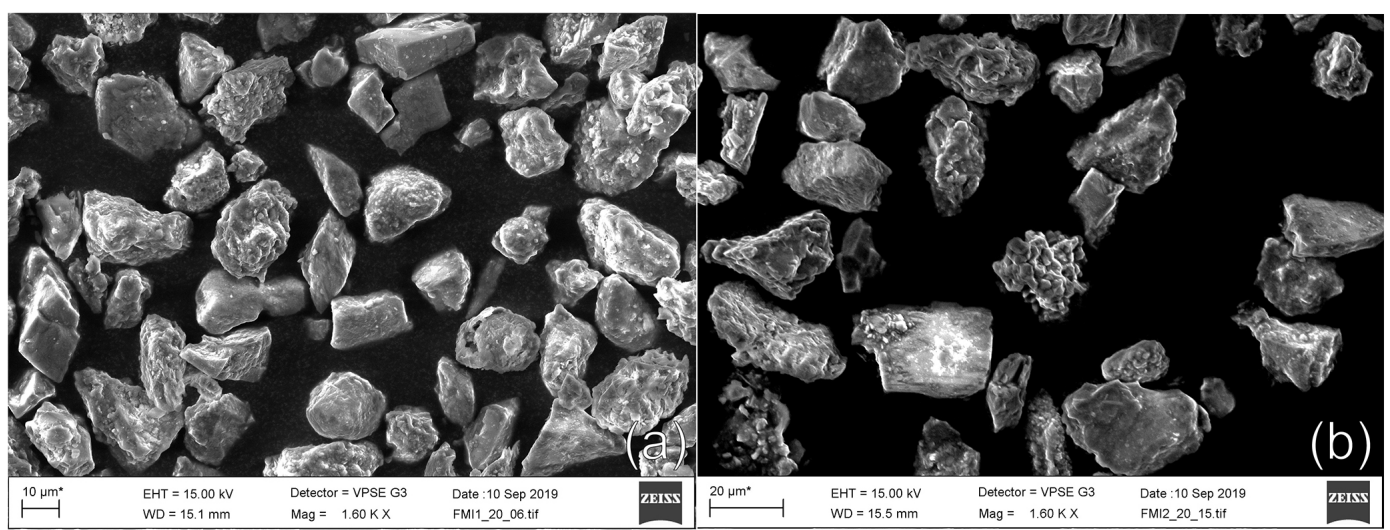

Figure A1. SEM pictures of the two dust samples. (a) Sample 1; (b) sample 2.

Table A1. Chemical composition of the two dust samples. The numbers show the minimum/maximum value of the elements found in the sample.

\begin{tabular}{lrr}
\hline Weight $\%$ & Sample 1 & Sample 2 \\
\hline $\mathrm{O}$ & $45.82-64.49$ & $50.79-59.25$ \\
$\mathrm{~F}$ & - & 6.17 \\
$\mathrm{Na}$ & $0.48-3.38$ & $0.55-2.10$ \\
$\mathrm{Mg}$ & $2.68-6.30$ & $2.66-10.04$ \\
$\mathrm{Al}$ & $1.48-10.88$ & $1.79-3.38$ \\
$\mathrm{Si}$ & $5.45-23.89$ & $6.09-35.87$ \\
$\mathrm{~S}$ & $0.30-15.87$ & $0.21-1.93$ \\
$\mathrm{~K}$ & $0.30-5.39$ & $0.21-0.74$ \\
$\mathrm{Ca}$ & $6.43-33.55$ & $4.04-32.33$ \\
$\mathrm{Ti}$ & - & $0.83-35.88$ \\
$\mathrm{Fe}$ & $1.20-12.33$ & $2.08-5.62$ \\
$\mathrm{Ba}$ & 0.90 & - \\
$\mathrm{Cl}$ & 0.20 & - \\
\hline
\end{tabular}


Data availability. The data used in this work are available upon request.

Author contributions. MF, MK and EG conceptualized and finalized the methodology. MF and MK were responsible for the lidar data and collection of the dust samples; RE and XS helped with the upkeep of the data and troubleshooting of the instrument. JL analysed the dust samples. MF performed the data analysis and wrote the paper. All the co-authors were involved in the paper editing, interpretation of the results, and discussion of the manuscript.

Competing interests. The authors declare that they have no conflict of interest.

Acknowledgements. This work was supported by the National Center of Meteorology, Abu Dhabi, UAE, under the UAE Research Program for Rain Enhancement Science. The authors are grateful to the NOAA Air Resources Laboratory (ARL) for the provision of the HySPLIT transport and dispersion model used in this publication. The EM facility of SIB Labs at the University of Eastern Finland is thanked for providing their SEM and EDX equipment to the study. We would also like to thank Timo Anttila and Siddharth Tampi for providing on-site technical support.

Financial support. This research has been supported by the H2020 European Research Council (ECLAIR, grant no. 646857) and the Academy of Finland, Biotieteiden ja Ympäristön Tutkimuksen Toimikunta (grant no. 270108).

Review statement. This paper was edited by Stelios Kazadzis and reviewed by three anonymous referees.

\section{References}

Ali, M. A., Assiri, M., and Dambul, R.: Seasonal aerosol optical depth (AOD) variability using satellite data and its comparison over Saudi Arabia for the period 2002-2013, Aerosol Air Qual. Res., 17, 1267-1280, https://doi.org/10.4209/aaqr.2016.11.0492, 2017.

Amiridis, V., Wandinger, U., Marinou, E., Giannakaki, E., Tsekeri, A., Basart, S., Kazadzis, S., Gkikas, A., Taylor, M., Baldasano, J., and Ansmann, A.: Optimizing CALIPSO Saharan dust retrievals, Atmos. Chem. Phys., 13, 12089-12106, https://doi.org/10.5194/acp-13-12089-2013, 2013.

Ansmann, A., Riebesell, M., and Weitkamp, C.: Measurement of atmospheric aerosol extinction profiles with a Raman lidar, Opt. Lett., 15, 746-748, https://doi.org/10.1364/ol.15.000746, 1990.

Ansmann, A., Riebesell, M., Wandinger, U., Weitkamp, C., Voss, E., Lahmann, W., and Michaelis, W.: Combined raman elasticbackscatter LIDAR for vertical profiling of moisture, aerosol extinction, backscatter, and LIDAR ratio, Appl. Phys. B, 55, 1828, https://doi.org/10.1007/BF00348608, 1992.
Ansmann, A., Tesche, M., Seifert, P., Althausen, D., Engelmann, R., Fruntke, J., Wandinger, U., Mattis, I., and Müller, D.: Evolution of the ice phase in tropical altocumulus: SAMUM lidar observations over Cape Verde, J. Geophys. Res., 114, D17208, https://doi.org/10.1029/2008JD011659, 2009.

Baars, H., Ansmann, A., Engelmann, R., and Althausen, D.: Continuous monitoring of the boundary-layer top with lidar, Atmos. Chem. Phys., 8, 7281-7296, https://doi.org/10.5194/acp-8-72812008, 2008.

Baars, H., Kanitz, T., Engelmann, R., Althausen, D., Heese, B., Komppula, M., Preißler, J., Tesche, M., Ansmann, A., Wandinger, U., Lim, J.-H., Ahn, J. Y., Stachlewska, I. S., Amiridis, V., Marinou, E., Seifert, P., Hofer, J., Skupin, A., Schneider, F., Bohlmann, S., Foth, A., Bley, S., Pfüller, A., Giannakaki, E., Lihavainen, H., Viisanen, Y., Hooda, R. K., Pereira, S. N., Bortoli, D., Wagner, F., Mattis, I., Janicka, L., Markowicz, K. M., Achtert, P., Artaxo, P., Pauliquevis, T., Souza, R. A. F., Sharma, V. P., van Zyl, P. G., Beukes, J. P., Sun, J., Rohwer, E. G., Deng, R., Mamouri, R.-E., and Zamorano, F.: An overview of the first decade of PollyNET: an emerging network of automated Raman-polarization lidars for continuous aerosol profiling, Atmos. Chem. Phys., 16, 5111-5137, https://doi.org/10.5194/acp16-5111-2016, 2016.

Betancourt-Torcat, A. and Almansoori, A.: Design multiperiod optimization model for the electricity sector under uncertainty - A case study of the Emirate of Abu Dhabi, Energy Convers. Manag., 100, 177-190, https://doi.org/10.1016/j.enconman.2015.05.001, 2015.

Binietoglou, I., Basart, S., Alados-Arboledas, L., Amiridis, V., Argyrouli, A., Baars, H., Baldasano, J. M., Balis, D., Belegante, L., Bravo-Aranda, J. A., Burlizzi, P., Carrasco, V., Chaikovsky, A., Comerón, A., D’Amico, G., Filioglou, M., Granados-Muñoz, M. J., Guerrero-Rascado, J. L., Ilic, L., Kokkalis, P., Maurizi, A., Mona, L., Monti, F., Muñoz-Porcar, C., Nicolae, D., Papayannis, A., Pappalardo, G., Pejanovic, G., Pereira, S. N., Perrone, M. R., Pietruczuk, A., Posyniak, M., Rocadenbosch, F., Rodríguez-Gómez, A., Sicard, M., Siomos, N., Szkop, A., Terradellas, E., Tsekeri, A., Vukovic, A., Wandinger, U., and Wagner, J.: A methodology for investigating dust model performance using synergistic EARLINET/AERONET dust concentration retrievals, Atmos. Meas. Tech., 8, 3577-3600, https://doi.org/10.5194/amt-8-3577-2015, 2015.

Bohlmann, S., Shang, X., Giannakaki, E., Filioglou, M., Saarto, A., Romakkaniemi, S., and Komppula, M.: Detection and characterization of birch pollen in the atmosphere using a multiwavelength Raman polarization lidar and Hirst-type pollen sampler in Finland, Atmos. Chem. Phys., 19, 14559-14569, https://doi.org/10.5194/acp-19-14559-2019, 2019.

Bösenberg, J., Matthias, V., Amodeo, A., Amoiridis, V., Ansmann,A., Baldasano, J. M., Balin, I., Balis, D., Böckmann, C., Boselli, A., Carlsson, G., Chaikovsky, A., Chourdakis, G., Comeron,A., De Tomasi, F., Eixmann, R., Freudenthaler, V., Giehl, H.,Grigorov, I., Hågård, A., Iarlori, M., Kirsche, A., Kolarov, G.,Komguem, L., Kreipl, S., Kumpf, S., Larchevêque, G., Linné, H.,Matthey, R., Mattis, I., Mekler, A., Mironova, I., Mitev, V., Mona,L., Müller, D., Music, S., Nickovic, S., Pandolfi, M., Papayannis,A., Pappalardo, G., Pelon, J., Pérez, C., Perrone, M. R., Persson,R., Resendes, D. P., Rizi, V., Rocadenbosch, F., Rodrigues, J. A.,Sauvage, L., Schneidenbach, L., Schumacher, 
R., Shcherbakov,V., Simeonov, V., Sobolewski, P., Spinelli, N., Stachlewska, I.,Stoyanov, D., Trickl, T., Tsaknakis, G., Vaughan, G., Wandinger,U., Wang, X., Wiegner, M., Zavrtanik, M., and Zerefos, C.: EARLINET: a European Aerosol Research Lidar Network to Estab-lish an Aerosol Climatology, MPI-Report 348, Hamburg, 2003.

Boucher, O., Randall, D., Artaxo, P., Bretherton, C., Feingold, G., Forster, P., Kerminen, V. M., Kondo, Y., Liao, H., Lohmann, U., Rasch, P., Satheesh, S. K., Sherwood, S., Stevens, B., and Zhang, X. Y.: Clouds and Aerosols, in: Climate Change 2013 - The Physical Science Basis, edited by Intergovernmental Panel on Climate Change, Cambridge University Press, Cambridge, 571658,2013

Coopman, Q., Garrett, T. J., Finch, D. P., and Riedi, J.: High Sensitivity of Arctic Liquid Clouds to Long-Range Anthropogenic Aerosol Transport, Geophys. Res. Lett., 45, 372-381, https://doi.org/10.1002/2017GL075795, 2018.

Davidson, C. I., Phalen, R. F., and Solomon, P. A.: Airborne Particulate Matter and Human Health: A Review, Aerosol Sci. Technol., 39, 737-749, https://doi.org/10.1080/02786820500191348, 2005.

DeMott, P. J., Sassen, K., Poellot, M. R., Baumgardner, D., Rogers, D. C., Brooks, S. D., Prenni, A. J., and Kreidenweis, S. M.: African dust aerosols as atmospheric ice nuclei, Geophys. Res. Lett., 30, 1732, https://doi.org/10.1029/2003GL017410, 2003.

Di Biagio, C., Formenti, P., Balkanski, Y., Caponi, L., Cazaunau, M., Pangui, E., Journet, E., Nowak, S., Caquineau, S., Andreae, M. O., Kandler, K., Saeed, T., Piketh, S., Seibert, D., Williams, E., and Doussin, J.-F.: Global scale variability of the mineral dust long-wave refractive index: a new dataset of in situ measurements for climate modeling and remote sensing, Atmos. Chem. Phys., 17, 1901-1929, https://doi.org/10.5194/acp17-1901-2017, 2017.

Di Biagio, C., Formenti, P., Balkanski, Y., Caponi, L., Cazaunau, M., Pangui, E., Journet, E., Nowak, S., Andreae, M. O., Kandler, K., Saeed, T., Piketh, S., Seibert, D., Williams, E., and Doussin, J.-F.: Complex refractive indices and single-scattering albedo of global dust aerosols in the shortwave spectrum and relationship to size and iron content, Atmos. Chem. Phys., 19, 15503-15531, https://doi.org/10.5194/acp-19-15503-2019, 2019.

Dubovik, O., Holben, B. N., Lapyonok, T., Sinyuk, A., Mishchenko, M. I., Yang, P., and Slutsker, I.: Non-spherical aerosol retrieval method employing light scattering by spheroids, Geophys. Res. Lett., 29, 54-1-54-4, https://doi.org/10.1029/2001GL014506, 2002

Eck, T. F., Holben, B. N., Reid, J. S., Sinyuk, A., Dubovik, O., Smirnov, A., Giles, D., O’Neill, N. T., Tsay, S.-C., Ji, Q., Al Mandoos, A., Ramzan Khan, M., Reid, E. A., Schafer, J. S., Sorokine, M., Newcomb, W., and Slutsker, I.: Spatial and temporal variability of column-integrated aerosol optical properties in the southern Arabian Gulf and United Arab Emirates in summer, J. Geophys. Res., 113, D01204, https://doi.org/10.1029/2007JD008944, 2008.

Egan, G. W. and Hildeman, T. W.: Optical Properties of Inhomogeneous Materials, Elsevier, 1979.

Engelmann, R., Kanitz, T., Baars, H., Heese, B., Althausen, D., Skupin, A., Wandinger, U., Komppula, M., Stachlewska, I. S., Amiridis, V., Marinou, E., Mattis, I., Linné, H., and Ansmann, A.: The automated multiwavelength Raman polarization and water-vapor lidar PollyXT: the neXT generation, Atmos. Meas. Tech., 9, 1767-1784, https://doi.org/10.5194/amt-9-1767-2016, 2016.

Filioglou, M., Nikandrova, A., Niemelä, S., Baars, H., Mielonen, T., Leskinen, A., Brus, D., Romakkaniemi, S., Giannakaki, E., and Komppula, M.: Profiling water vapor mixing ratios in Finland by means of a Raman lidar, a satellite and a model, Atmos. Meas. Tech., 10, 4303-4316, https://doi.org/10.5194/amt10-4303-2017, 2017.

Filioglou, M., Mielonen, T., Balis, D., Giannakaki, E., Arola, A., Kokkola, H., Komppula, M., and Romakkaniemi, S.: Aerosol Effect on the Cloud Phase of Low-Level Clouds Over the Arctic, J. Geophys. Res.-Atmos., 124, 7886-7899, https://doi.org/10.1029/2018JD030088, 2019.

French, J. R., Friedrich, K., Tessendorf, S. A., Rauber, R. M., Geerts, B., Rasmussen, R. M., Xue, L., Kunkel, M. L., and Blestrud, D. R.: Precipitation formation from orographic cloud seeding, P. Natl. Acad. Sci. USA, 115, 1168-1173, https://doi.org/10.1073/pnas.1716995115, 2018.

Giannakaki, E., Pfüller, A., Korhonen, K., Mielonen, T., Laakso, L., Vakkari, V., Baars, H., Engelmann, R., Beukes, J. P., Van Zyl, P. G., Josipovic, M., Tiitta, P., Chiloane, K., Piketh, S., Lihavainen, H., Lehtinen, K. E. J., and Komppula, M.: One year of Raman lidar observations of free-tropospheric aerosol layers over South Africa, Atmos. Chem. Phys., 15, 5429-5442, https://doi.org/10.5194/acp-15-5429-2015, 2015.

Giannakaki, E., van Zyl, P. G., Müller, D., Balis, D., and Komppula, M.: Optical and microphysical characterization of aerosol layers over South Africa by means of multi-wavelength depolarization and Raman lidar measurements, Atmos. Chem. Phys., 16, 81098123, https://doi.org/10.5194/acp-16-8109-2016, 2016.

Giannakaki, E., Kokkalis, P., Marinou, E., Bartsotas, N. S., Amiridis, V., Ansmann, A., and Komppula, M.: The potential of elastic and polarization lidars to retrieve extinction profiles, Atmos. Meas. Tech., 13, 893-905, https://doi.org/10.5194/amt13-893-2020, 2020.

Guffanti, M., Schneider, D. J., Wallace, K. L., Hall, T., Bensimon, D. R., and Salinas, L. J.: Aviation response to a widely dispersed volcanic ash and gas cloud from the August 2008 eruption of Kasatochi, Alaska, USA, J. Geophys. Res., 115, D00L19, https://doi.org/10.1029/2010JD013868, 2010.

Hansen, J., Nazarenko, L., Ruedy, R., Sato, M., Willis, J., Del Genio, A., Koch, D., Lacis, A., Lo, K., Menon, S., Novakov, T., Perlwitz, J., Russell, G., Schmidt, G. A., and Tausnev, N.: Earth's energy imbalance: confirmation and implications, Science, 308, 1431-1435, https://doi.org/10.1126/science.1110252, 2005.

Hirsikko, A., O'Connor, E. J., Komppula, M., Korhonen, K., Pfüller, A., Giannakaki, E., Wood, C. R., Bauer-Pfundstein, M., Poikonen, A., Karppinen, T., Lonka, H., Kurri, M., Heinonen, J., Moisseev, D., Asmi, E., Aaltonen, V., Nordbo, A., Rodriguez, E., Lihavainen, H., Laaksonen, A., Lehtinen, K. E. J., Laurila, T., Petäjä, T., Kulmala, M., and Viisanen, Y.: Observing wind, aerosol particles, cloud and precipitation: Finland's new groundbased remote-sensing network, Atmos. Meas. Tech., 7, 13511375, https://doi.org/10.5194/amt-7-1351-2014, 2014.

Hofer, J., Althausen, D., Abdullaev, S. F., Makhmudov, A. N., Nazarov, B. I., Schettler, G., Engelmann, R., Baars, H., Fomba, K. W., Müller, K., Heinold, B., Kandler, K., and Ansmann, A.: Long-term profiling of mineral dust and pollution aerosol 
with multiwavelength polarization Raman lidar at the Central Asian site of Dushanbe, Tajikistan: case studies, Atmos. Chem. Phys., 17, 14559-14577, https://doi.org/10.5194/acp-17-145592017, 2017.

Hoshyaripour, G. A., Bachmann, V., Förstner, J., Steiner, A., Vogel, H., Wagner, F., Walter, C., and Vogel, B.: Effects of Particle Nonsphericity on Dust Optical Properties in a Forecast System: Implications for Model-Observation Comparison, J. Geophys. Res.-Atmos., 124, 2018JD030228, https://doi.org/10.1029/2018JD030228, 2019.

Järvinen, E., Kemppinen, O., Nousiainen, T., Kociok, T., Möhler, O., Leisner, T., and Schnaiter, M.: Laboratory investigations of mineral dust near-backscattering depolarization ratios, J. Quant. Spectrosc. Ra., 178, 192-208, https://doi.org/10.1016/J.JQSRT.2016.02.003, 2016.

Kanakidou, M., Myriokefalitakis, S., and Tsigaridis, K.: Aerosols in atmospheric chemistry and biogeochemical cycles of nutrients, Environ. Res. Lett., 13, 063004, https://doi.org/10.1088/17489326/aabcdb, 2018.

Karydis, V. A., Kumar, P., Barahona, D., Sokolik, I. N., and Nenes, A.: On the effect of dust particles on global cloud condensation nuclei and cloud droplet number, J. Geophys. Res.-Atmos., 116, D23204, https://doi.org/10.1029/2011JD016283, 2011.

Kim, D., Chin, M., Yu, H., Eck, T. F., Sinyuk, A., Smirnov, A., and Holben, B. N.: Dust optical properties over North Africa and Arabian Peninsula derived from the AERONET dataset, Atmos. Chem. Phys., 11, 10733-10741, https://doi.org/10.5194/acp-1110733-2011, 2011.

Kim, M.-H., Omar, A. H., Tackett, J. L., Vaughan, M. A., Winker, D. M., Trepte, C. R., Hu, Y., Liu, Z., Poole, L. R., Pitts, M. C., Kar, J., and Magill, B. E.: The CALIPSO version 4 automated aerosol classification and lidar ratio selection algorithm, Atmos. Meas. Tech., 11, 6107-6135, https://doi.org/10.5194/amt11-6107-2018, 2018.

Kok, J. F., Ridley, D. A., Zhou, Q., Miller, R. L., Zhao, C., Heald, C. L., Ward, D. S., Albani, S., and Haustein, K.: Smaller desert dust cooling effect estimated from analysis of dust size and abundance, Nat. Geosci., 10, 274-278, https://doi.org/10.1038/ngeo2912, 2017.

Komppula, M., Mielonen, T., Arola, A., Korhonen, K., Lihavainen, H., Hyvärinen, A.-P., Baars, H., Engelmann, R., Althausen, D., Ansmann, A., Müller, D., Panwar, T. S., Hooda, R. K., Sharma, V. P., Kerminen, V.-M., Lehtinen, K. E. J., and Viisanen, Y.: Technical Note: One year of Raman-lidar measurements in Gual Pahari EUCAARI site close to New Delhi in India - Seasonal characteristics of the aerosol vertical structure, Atmos. Chem. Phys., 12, 4513-4524, https://doi.org/10.5194/acp12-4513-2012, 2012

Korhonen, K., Giannakaki, E., Mielonen, T., Pfüller, A., Laakso, L., Vakkari, V., Baars, H., Engelmann, R., Beukes, J. P., Van Zyl, P. G., Ramandh, A., Ntsangwane, L., Josipovic, M., Tiitta, P., Fourie, G., Ngwana, I., Chiloane, K., and Komppula, M.: Atmospheric boundary layer top height in South Africa: measurements with lidar and radiosonde compared to three atmospheric models, Atmos. Chem. Phys., 14, 4263-4278, https://doi.org/10.5194/acp-14-4263-2014, 2014.

Kutiel, H. and Furman, H.: Dust Storms in the Middle East: Sources of Origin and their Temporal Characteristics, in: Indoor and Built Environment, 12, 419-426, 2003.
Lechner, P., Tupper, A., Guffanti, M., Loughlin, S., and Casadevall, T.: Volcanic Ash and Aviation - The Challenges of Real-Time, Global Communication of a Natural Hazard, Springer, Cham., 51-64, 2017.

Li, J., Lv, Q., Zhang, M., Wang, T., Kawamoto, K., Chen, S., and Zhang, B.: Effects of atmospheric dynamics and aerosols on the fraction of supercooled water clouds, Atmos. Chem. Phys., 17 1847-1863, https://doi.org/10.5194/acp-17-1847-2017, 2017.

Li, Y., Gibson, J. M. D., Jat, P., Puggioni, G., Hasan, M., West, J. J., Vizuete, W., Sexton, K., and Serre, M. Burden of disease attributed to anthropogenic air pollution in the United Arab Emirates: Estimates based on observed air quality data, Sci. Total Environ., 408, 5784-5793, https://doi.org/10.1016/j.scitotenv.2010.08.017, 2010.

Mamouri, R. E., Ansmann, A., Nisantzi, A., Kokkalis, P., Schwarz, A., and Hadjimitsis, D.: Low Arabian dust extinctionto-backscatter ratio, Geophys. Res. Lett., 40, 4762-4766, https://doi.org/10.1002/grl.50898, 2013a.

Mamouri, R. E., Ansmann, A., Nisantzi, A., Kokkalis, P., Schwarz, A., and Hadjimitsis, D.: Low Arabian dust extinctionto-backscatter ratio, Geophys. Res. Lett., 40, 4762-4766, https://doi.org/10.1002/grl.50898, 2013 b.

Miller, R. L., Cakmur, R. V., Perlwitz, J., Geogdzhayev, I. V., Ginoux, P., Koch, D., Kohfeld, K. E., Prigent, C., Ruedy, R., Schmidt, G. A., and Tegen, I.: Mineral dust aerosols in the NASA Goddard Institute for Space Sciences ModelE atmospheric general circulation model, J. Geophys. Res., 111, D06208, https://doi.org/10.1029/2005JD005796, 2006.

Moore, J. K. and Braucher, O.: Sedimentary and mineral dust sources of dissolved iron to the world ocean, Biogeosciences, 5, 631-656, https://doi.org/10.5194/bg-5-631-2008, 2008.

Morrison, H., Shupe, M. D., Pinto, J. O., and Curry, J. A.: Possible roles of ice nucleation mode and ice nuclei depletion in the extended lifetime of Arctic mixed-phase clouds, Geophys. Res. Lett., 32, L18801, https://doi.org/10.1029/2005GL023614, 2005.

Müller, D., Ansmann, A., Mattis, I., Tesche, M., Wandinger, U., Althausen, D., and Pisani, G.: Aerosol-type-dependent lidar ratios observed with Raman lidar, J. Geophys. Res., 112, D16202, https://doi.org/10.1029/2006JD008292, 2007.

Nicolae, D., Vasilescu, J., Talianu, C., Binietoglou, I., Nicolae, V., Andrei, S., and Antonescu, B.: A neural network aerosol-typing algorithm based on lidar data, Atmos. Chem. Phys., 18, 1451114537, https://doi.org/10.5194/acp-18-14511-2018, 2018.

Nisantzi, A., Mamouri, R. E., Ansmann, A., Schuster, G. L., and Hadjimitsis, D. G.: Middle East versus Saharan dust extinctionto-backscatter ratios, Atmos. Chem. Phys., 15, 7071-7084, https://doi.org/10.5194/acp-15-7071-2015, 2015.

Papagiannopoulos, N., Mona, L., Alados-Arboledas, L., Amiridis, V., Baars, H., Binietoglou, I., Bortoli, D., D’Amico, G., Giunta, A., Guerrero-Rascado, J. L., Schwarz, A., Pereira, S., Spinelli, N., Wandinger, U., Wang, X., and Pappalardo, G.: CALIPSO climatological products: evaluation and suggestions from EARLINET, Atmos. Chem. Phys., 16, 2341-2357, https://doi.org/10.5194/acp-16-2341-2016, 2016.

Papagiannopoulos, N., Mona, L., Amodeo, A., D’Amico, G., Gumà Claramunt, P., Pappalardo, G., Alados-Arboledas, L., GuerreroRascado, J. L., Amiridis, V., Kokkalis, P., Apituley, A., Baars, H., Schwarz, A., Wandinger, U., Binietoglou, I., Nicolae, D., Bortoli, D., Comerón, A., Rodríguez-Gómez, A., Sicard, M., Papayannis, 
A., and Wiegner, M.: An automatic observation-based aerosol typing method for EARLINET, Atmos. Chem. Phys., 18, 1587915901, https://doi.org/10.5194/acp-18-15879-2018, 2018.

Pappalardo, G., Amodeo, A., Apituley, A., Comeron, A., Freudenthaler, V., Linné, H., Ansmann, A., Bösenberg, J., D’Amico, G., Mattis, I., Mona, L., Wandinger, U., Amiridis, V., AladosArboledas, L., Nicolae, D., and Wiegner, M.: EARLINET: towards an advanced sustainable European aerosol lidar network, Atmos. Meas. Tech., 7, 2389-2409, https://doi.org/10.5194/amt7-2389-2014, 2014.

Querry, M.: Optical constants of minerals and other materials from the millimeter to the ultraviolet, US Army Armament Munitions \& Chemical Research Development \& Engineering Center, Aberdeen Proving Ground Md., 1987.

Ramanathan, V., Crutzen, P. J., Lelieveld, J., Mitra, A. P., Althausen, D., Anderson, J., Andreae, M. O., Cantrell, W., Cass, G. R., Chung, C. E., Clarke, A. D., Coakley, J. A., Collins, W. D., Conant, W. C., Dulac, F., Heintzenberg, J., Heymsfield, A. J., Holben, B., Howell, S., Hudson, J., Jayaraman, A., Kiehl, J. T., Krishnamurti, T. N., Lubin, D., McFarquhar, G., Novakov, T., Ogren, J. A., Podgorny, I. A., Prather, K., Priestley, K., Prospero, J. M., Quinn, P. K., Rajeev, K., Rasch, P., Rupert, S., Sadourny, R., Satheesh, S. K., Shaw, G. E., Sheridan, P., and Valero, F. P. J.: Indian Ocean Experiment: An integrated analysis of the climate forcing and effects of the great Indo-Asian haze, J. Geophys. Res.-Atmos., 106, 28371-28398, https://doi.org/10.1029/2001JD900133, 2001.

Rosenfeld, D.: Cloud-Aerosol-Precipitation Interactions Based of Satellite Retrieved Vertical Profiles of Cloud Microstructure, in: Remote Sensing of Aerosols, Clouds, and Precipitation, Elsevier, 129-152, https://doi.org/10.1016/B978-0-12-810437-8.00006-2, 2018.

Roshan, D. R., Koc, M., Isaifan, R., Shahid, M. Z., and Fountoukis, C.: Aerosol Optical Thickness over Large Urban Environments of the Arabian Peninsula-Speciation, Variability, and Distributions, Atmosphere, 10, 228, https://doi.org/10.3390/atmos10050228, 2019.

Rushdi, A. I., El-Mubarak, A. H., Lijotra, L., Al-Otaibi, M. T., Qurban, M. A., Al-Mutlaq, K. F., and Simoneit, B. R. T.: Characteristics of organic compounds in aerosol particulate matter from Dhahran city, Saudi Arabia, Arab. J. Chem., 10, S3532-S3547, https://doi.org/10.1016/j.arabjc.2014.03.001, 2017.

Schuster, G. L., Vaughan, M., MacDonnell, D., Su, W., Winker, D., Dubovik, O., Lapyonok, T., and Trepte, C.: Comparison of CALIPSO aerosol optical depth retrievals to AERONET measurements, and a climatology for the lidar ratio of dust, Atmos. Chem. Phys., 12, 7431-7452, https://doi.org/10.5194/acp12-7431-2012, 2012.

Shin, S.-K., Tesche, M., Kim, K., Kezoudi, M., Tatarov, B., Müller, D., and Noh, Y.: On the spectral depolarisation and lidar ratio of mineral dust provided in the AERONET version 3 inversion product, Atmos. Chem. Phys., 18, 12735-12746, https://doi.org/10.5194/acp-18-12735-2018, 2018.

Sokolik, I. N. and Toon, O. B.: Incorporation of mineralogical composition into models of the radiative properties of mineral aerosol from UV to IR wavelengths, J. Geophys. Res.-Atmos., 104, 9423-9444, https://doi.org/10.1029/1998JD200048, 1999.

Stein, A. F., Draxler, R. R., Rolph, G. D., Stunder, B. J. B., Cohen, M. D., and Ngan, F.: Noaa'S Hysplit Atmospheric Transport And
Dispersion Modeling System, B. Am. Meteorol. Soc., 96, 20592078, https://doi.org/10.2307/26233118, 2015.

Stevens, B. and Feingold, G.: Untangling aerosol effects on clouds and precipitation in a buffered system, Nature, 461, 607-613, https://doi.org/10.1038/nature08281, 2009.

Tesche, M., Ansmann, A., MüLLER, D., Althausen, D., Mattis, I., Heese, B., Freudenthaler, V., Wiegner, M., Esselborn, M., Pisani, G., and Knippertz, P.: Vertical profiling of Saharan dust with Raman lidars and airborne HSRL in southern Morocco during SAMUM, Tellus B, 61, 144-164, https://doi.org/10.1111/j.16000889.2008.00390.x, 2009.

Ukhov, A., Mostamandi, S., Anisimov, A., and Stenchikov, G.: Natural and anthropogenic air pollution in the Middle East, 20th EGU General Assembly, EGU2018, Vienna, Austria, 413 April 2018, EGU2018-9833 2018.

Vaughan, M. A., Powell, K. A., Winker, D. M., Hostetler, C. A., Kuehn, R. E., Hunt, W. H., Getzewich, B. J., Young, S. A., Liu, Z., and McGill, M. J.: Fully Automated Detection of Cloud and Aerosol Layers in the CALIPSO Lidar Measurements, J. Atmos. Ocean. Tech., 26, 2034-2050, https://doi.org/10.1175/2009JTECHA1228.1, 2009.

Vonnegut, B. and Chessin, H.: Ice nucleation by coprecipitated silver iodide and silver bromide, Science, 174, 945-6, https://doi.org/10.1126/science.174.4012.945, 1971.

Wagner, R., Ajtai, T., Kandler, K., Lieke, K., Linke, C., Müller, T., Schnaiter, M., and Vragel, M.: Complex refractive indices of Saharan dust samples at visible and near UV wavelengths: a laboratory study, Atmos. Chem. Phys., 12, 2491-2512, https://doi.org/10.5194/acp-12-2491-2012, 2012.

Wehbe, Y., Ghebreyesus, D., Temimi, M., Milewski, A., and $\mathrm{Al}$ Mandous, A.: Assessment of the consistency among global precipitation products over the United Arab Emirates, J. Hydrol. Reg. Stud., 12, 122-135, https://doi.org/10.1016/J.EJRH.2017.05.002, 2017.

Whiteman, D. N.: Examination of the traditional Raman lidar technique I Evaluating the temperature-dependent lidar equations, Appl. Opt., 42, 2571, https://doi.org/10.1364/ao.42.002571, 2003.

Wiegner, M., Gasteiger, J., Kandler, K., Weinzierl, B., Rasp, K., Esselborn, M., Freudenthaler, V., Heese, B., Toledano, C., Tesche, M., and Althausen, D.: Numerical simulations of optical properties of Saharan dust aerosols with emphasis on lidar applications, Tellus B, 61, 180-194, https://doi.org/10.1111/j.16000889.2008.00381.x, 2009.

Yu, Y., Notaro, M., Kalashnikova, O. V., and Garay, M. J.: Climatology of summer Shamal wind in the Middle East, J. Geophys. Res.-Atmos., 121, 289-305, https://doi.org/10.1002/2015JD024063, 2016.

Zamora, L. M., Kahn, R. A., Eckhardt, S., McComiskey, A., Sawamura, P., Moore, R., and Stohl, A.: Aerosol indirect effects on the nighttime Arctic Ocean surface from thin, predominantly liquid clouds, Atmos. Chem. Phys., 17, 7311-7332, https://doi.org/10.5194/acp-17-7311-2017, 2017. 